高分子論文集 (Kobunshi Ronbunshu), Vol. 40, No. 12, pp. 795 -799 (Dec., 1983)

\title{
ポリビニルアルコールゲルカラムの各種溶媒系における ポリエチレングリコールの溶出挙動
}

\author{
平山 忠一*1 - 松本 和秋*2 - 本里 義明*1
}

(受付 1982 年 12 月 9 日・雷查終了 1983 年 8 月 10 日)

\begin{abstract}
要 旨 $\gamma$ 線照射して得たポリビニルアルコール球状ゲル粒子を水中で膨潤させ，メタノール置換 した後カラムに充てんした。溶出溶媒としてメタノール，ベンゼン，エステル類，ケトン類を，試料 としてポリェチレングリコールを用いてゲルクロマトグラフィーを行った。溶出溶媒がメタノール, ベンゼンの場合はポリエチレングリコールは正常位罱で溶出し，ギ酸エチル，酢酸メチル，プロピオ ン酸エチルの場合は遅れて溶出し, 酢酸エチル, 酢酸プロピル, 酢酸ブチル, エチルメチルケトンの 場合は吸着し，その吸着量曲線は較正曲線に類似している。充てル剤として乾燥したポリビニルアル コールゲル档子在，溶出溶媒として酢酸エチルを用いた場合はポリエチレングリコールは溶出してく る.このこレからポリエチレングリコールのゲル床への吸着はポリビニルアルコールゲルマトリック ス中の水和水の存在に上ると考えら机る。
\end{abstract}

\section{1 緒霉}

著者らはポリビニルアルコール (PVA) を素材とした ゲルクロマトグラフィーー水系充てん剂を合成し，水を

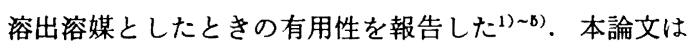
これらのらち 線照射によって得られた PVA ゲル粒子 についてカラム充てん剤としての適性を, ポリェチレン グリコール (PEG) の溶出挙動を各種溶媒について調べ ることによって検討した. その結果, 溶出溶媒の種類と PVA ゲル粒子中の水和水の有無が PEG の溶出挙動に 影響を与えることなど興味ある事実が判明したので報告 する.

\section{2 実 験}

\section{1 試莱}

酢酸ビニル，酢酸メチル，酢酸エチル，メタノール， アセトン, ベンゼンは試薬一級品を常圧下蒸留しそれぞ れ 72.5 73.0, 56.3 59.8, 76.3 76.8, 64.2 64.7, $56.0 \sim 56.3,79.6 \sim 80.1^{\circ} \mathrm{C}$ の留分を使用した. ギ酸エチ ル，酢酸ブチル，酢酸プロピル，プロピオン酸エチル， エチルメチルケトン, ジェチルケトンは試薬特級品を, その他の試薬は試薬一級品をそのまま使用した.

\subsection{PVA 球状ゲルの調製}

酢酸ビニルを㲘濁重合して得たポリ酢酸ビニル球状粒

*1 熊本大学 (恶860 熊本市黒髮 2-39-1)

*2 有明工業高等専門学校（业836大牛用市東荻尾町 150)
子を既報 ${ }^{3)}$ の方法でケン化して PVA 球状粒子を製造し た. 粒子をふるい分けて 100〜150メッシュにそろえた。 PVA の粘度法 ${ }^{()}$から求めた平均分子量は 67000 , ケン 化度7) は98.8 モル\%であった。一方の端をとじたガラ ス管中に，PVA 球状粒子をつめて開管のまま $5 \mathrm{wt} \%$ 硫酸ナトリウム水溶液中, 常温で $\gamma$ 線照射してPVA 球 状ゲルを調製した 線源は日本原子力研究所東海研究所 $\mathrm{Co}^{80} 45 \mathrm{Kci}$, 線量率 $1.00 \times 10^{8}(\mathrm{R} / \mathrm{h})$, 全線量 $1.00 \times$ $10^{8}(\mathrm{R})$ である.

\section{3 ゲルクロマトクラフィー}

溶出溶媒としては㼍酸メチル，酢酸エチル，酢酸プロ ピル，酢酸ブチル，ギ酸エチル，プロピオン酸エチル， メタノール, アセトン, ペンゼン, エチルメチルケト ン, ジェチルケトンを用い, 溶出試料としては Table 1 に示す PSt, PEG, 各種溶媒を, それぞれの溶出溶媒に 対して $5 \mathrm{wt} \%$ 溶液として使用した。 また各試料の注入 量は, PSt·12 20 $\mu l$, PEG $30 \mu l$, 各種有機溶媒 $20 \mu l$ である. PEG の分子量 $M_{n}$ はェブリオメーター (L4 型, 宝工業(株)）で測定した．PVA ゲルは， $\gamma$ 線照射 後十分に水洗して硫酸ナトリウムを除去し，水中で $60^{\circ} \mathrm{C}, 6$ 時間膨潤させ, 径 $1 \mathrm{~cm}$ のガラスカラムに充て んしてメタノールを流して水をメタノールに固換した. これを取り出しメタノールスラリーとし内径 $0.5 \mathrm{~cm}$, 長さ $50 \mathrm{~cm}$ のガラスカラム (可動栓サンプルインジェ クタ一付，協和精密 (株) 製) にスラリー法によって充て んし, 溶出溶媒がメタノールの場合はこのままクロマト グラフィーに使用し, 他の有機溶媒の場合はそれぞれの 
Table 1. Molecular characteristics of samples used for gel chromatography

\begin{tabular}{lr}
\hline \multicolumn{1}{c}{ Samplea) $^{\text {a }}$} & \multicolumn{1}{c}{$M_{n}$} \\
\hline PSt & 97200 \\
PEG-20M & 28100 \\
PEG-9000 & 10800 \\
PEG-4000 & 3550 \\
PEG-1540 & 2550 \\
PEG-1500 & 1520 \\
PEG-1000 & 710 \\
PEG- 600 & 680 \\
PEG- 400 & 470 \\
PEG- 200 & 220 \\
EG & 62 \\
Methyl acetate & 74 \\
Ethyl acetate & 88 \\
Propyl acetate & 102 \\
Buthyl acetete & 116 \\
Ethyl formate & 74 \\
Ethyl propionate & 102 \\
Acetone & 58 \\
Ethyl methyl ketone & 72 \\
Diethyl ketone & 86 \\
\hline
\end{tabular}

a) PSt, polystyrene; PEG, poly(ethylene glycol); $\mathrm{EG}$, ethylene glycol.

溶媒をカラム体積の 20 倍量流して使用した. ピークの 検出は示差屈折計 (Model R-401, Waters Associates) を用いた，得られた溶出曲線のピークの溶出量とその試 料の分子量の関係から較正曲線を求めた. その中央の直 線部分は次式で表される ${ }^{8)}$.

$\log M=\beta-\alpha\left(V_{\mathrm{e}} / V_{\mathrm{t}}\right)$

ここで $V_{\mathrm{t}}$ はゲル床客積， $V_{\mathrm{e}}$ は分子量 $M$ の試料の 溶出容積. また較正曲線の中央の直線部分を $V_{0}$ (ゲル 床間隙容積）の值まで外插して排除限界分子量 $\left(M_{11 \mathrm{n}}\right)$ を求めた。

\section{3 結果と考察}

\section{1 各種溶出溶媒ての PEG の溶出挙動}

Fig. 1 はベンゼン, メタノールを溶出溶媒に, PEG を試料として PVA ゲルカラムを用いてゲルクロマトグ ラフィーを行った結果である. この結果, ベンゼン, メ タノールを溶出溶媒としたときは, PVA ゲルが水系充 てん阂であるにもかかわらず，水を溶出溶媒として PEG を溶出した場合と同様に分子量の大きな順に溶出 した.このことは PEG が分子サイズに応じて PVA ゲ ル中に浸透した結果サイズセパレーションが行れたこと を示している．図中，同一カラムを使用したにもかかわ らず溶出溶媒としてベンゼンを用いた方がメタノールの 場合より $M_{11 \mathrm{~m}}$ が小さくなっている，これは両溶媒中で
のゲル空孔の変化の寄与と両溶媒中での PEG の広がり の差の寄与の両者が影響していると考えられる.すなわ ち前者については Table 2 に示した両溶媒中でのゲル の膨潤度がメタノール中での方が大きいことからゲル空 孔がより広がっていること, 後者については次に示す著 者が測定した PEG の両溶媒中での粘度式から同一分子 量の PEG はベンビン中での方が広がりが大きいことに よると考えられる.

$$
\begin{aligned}
& {[\eta]=K M^{a}} \\
& \text { ベンゼン }\left(25^{\circ} \mathrm{C}\right) \text { のとき } \\
& K=3.98 \times 10^{-5} ; a=0.69 \\
& \text { メタノール }\left(25^{\circ} \mathrm{C}\right) \text { のとき } \\
& K=8.40 \times 10^{-5} ; a=0.56
\end{aligned}
$$

次に酢酸エチルを溶出溶媒としたときは，サンプルの PEG 及びェチレングリュールは全く溶出してこない. これは PEG, エチレングリコールが PVA ゲルに完全 に吸着されたためと考えられる． また PSt は $V_{0}$ の位 置で溶出した. そこで酢酸エチルを溶出溶媒として PVA ゲルへの PEG の吸着・脱着に関する検討を行っ た. PSt の $5 \mathrm{wt} \%$ 酢酸エチル溶液 $12 \mu \mathrm{l}$ をPVA ゲル カラムに注入したところ吸着されずに $V_{0}$ の位置で溶出 した (Fig. 2(a)). PEG-4000 $\left(M_{n}=3550\right)$ の $1 \mathrm{wt} \%$ 酢 酸エチル溶液を $30 \mu l$ 注入すると溶出しないか，同溶液 を連続して注入していくとある注入量のところで PEG が溶出してきた (Fig. 2(b)). つづいて酢酸エチルを多 量に流して PVA ゲル間隙の PEG 溶液を追い出した 後, PEG-4000 の $5 \mathrm{wt} \%$ 酢酸エチル溶液を $30 \mu l$ 注入 したところ、この PEG 試料は PSt と同じ溶出量で溶 出した (Fig. 2(c)). これは PVA ゲルへの PEG の吸 着量が既に飽和状態に達しているためにこれ以上吸着で きずに $V_{0}$ の溶出容積が溶出したことを示している. PEG を飽和させた PVA ゲルカラムにメタノールを多 量に流した後, 再度 PEG-4000の 1 wt\% 酢酸エチル溶 液を連続して注入していくと Fig. 2 (b) と同じ溶出量の ところで PEG が溶出してきた (Fig. 2(d)). このことは 酢酸エチルを溶媒としたときに PVA ゲルに吸着された PEG が，溶媒をメタノールに置換することにより完全 に脱着されることを示している。

酢酸エチルを溶出溶媒とした時 PEG-4000 は PVA ゲルに吸着されることが確認されたので，エステル類, ケトン類のらちからギ酸エチル, 酢酸メチル, 酢酸プロ ピル，酢酸ブチル，プロピオン酸エチル，フセトン，エ チルメチルケトン, ジェチルケトンのそれぞれの有機溶 媒を溶出溶媒として PVA ゲルカラムを用いて PEG4000 を溶出した. この結果，酢酸エチル，酢酸プロピ ル，酢酸ブチル及びェチルメチルケトンを溶媒としたと きに PEG-4000 は PVA ゲルに吸着され溶出しないこ とが確認された。䣫酸メチル，ギ酸エチル，プロピオン 
Table 2. Degree of swelling of gel in several solvents

\begin{tabular}{lcc}
\hline \hline Solvent & $\begin{array}{c}\text { Degree of swelling } \\
\text { (wet gel-bed } \mathrm{m} / \text { dry } \text { gel-g) }\end{array}$ & $\begin{array}{c}\text { Solvent regain } \\
\text { (solvent-g/dry gel-g) }\end{array}$ \\
\hline Methanol & 2.3 & 1.5 \\
Benzene & 1.7 & 1.2 \\
Ethyl acetate & 1.6 & 1.1 \\
Water & 3.0 & 1.3 \\
\hline
\end{tabular}

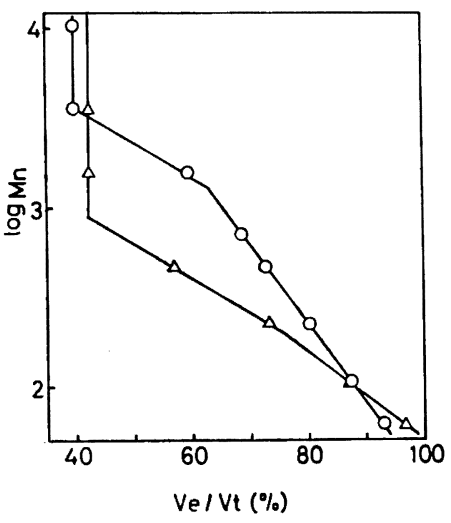

Fig. 1. Calibration curves for PVA gel column using poly(ethylene glycol) as a sample. Eluant: $\bigcirc$, Methanol; $\triangle$, Benzene.

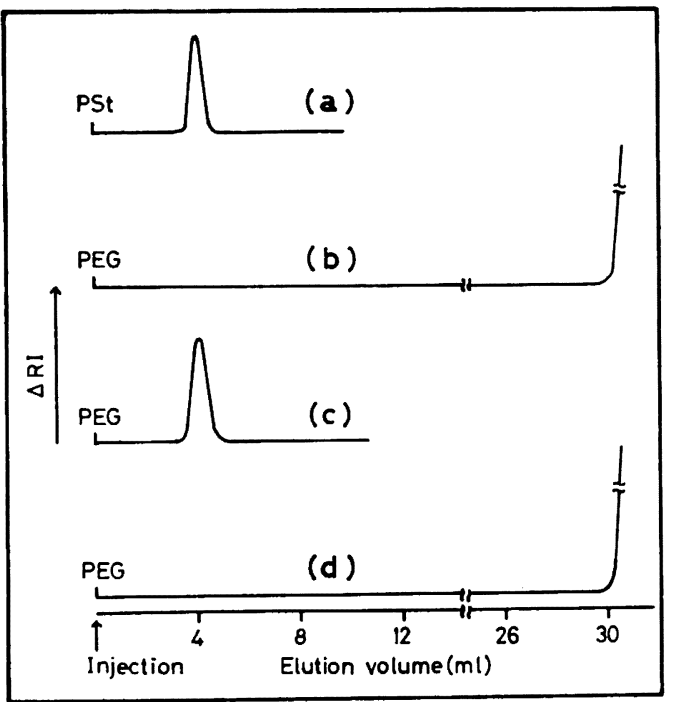

Fig. 2. Elution diagrams of PSt and PEG-4000 on PVA gel column using ethyl acetate as an eluent: Amount injected; (a) $12 \mu \mathrm{l}$ of $5 \mathrm{wt} \% \mathrm{PSt}$ solution, (b) Continuous injection of 1 wt $\%$ PEG solution till leak of PEG, (c) $30 \mu l$ of $5 \mathrm{wt} \%$ PEG solution into PVA gel column saturated with PEG, (d) Continuous injection of $1 \mathrm{wt} \%$ PEG solution after eluting excess methanol: Column; $0.5 \mathrm{~cm}$ i.d $\times 50 \mathrm{~cm}$.
Table 3. Elution volume of PEG-4000 on poly (vinyl alcohol) PVA gel column using several solvents as eluents

\begin{tabular}{|c|c|}
\hline Eluent & $\begin{array}{l}\text { Elution volume of PEG-4000 } \\
\qquad V_{\mathrm{e}} / V_{\mathrm{t}}(\%)\end{array}$ \\
\hline H- $\underset{\|}{\mathrm{O} O}-\mathrm{C}_{2} \mathrm{H}_{5}$ & 111.7 \\
\hline $\mathrm{CH}_{3}-\mathrm{CO}-\mathrm{CH}_{3}$ & 103.0 \\
\hline $\mathrm{CH}_{8}-\underset{11}{\mathrm{CO}}-\mathrm{C}_{2} \mathrm{H}_{5}$ & adsorp. \\
\hline$\underset{\mathrm{O}}{\mathrm{CH}_{3}}-\underset{\mathrm{CO}}{\mathrm{CO}}-\mathrm{C}_{3} \mathrm{H}_{7}$ & adsorp. \\
\hline$\underset{\mathrm{O}}{\mathrm{CH}_{3}-\mathrm{CO}-\mathrm{C}_{4} \mathrm{H}_{\theta}}$ & adsorp. \\
\hline$\underset{\stackrel{\mathrm{O}}{\mathrm{C}}}{\mathrm{C}_{8} \mathrm{H}_{7}-\mathrm{CO}-\mathrm{C}_{2} \mathrm{H}_{6}}$ & 138.2 \\
\hline$\underset{\text { OH }}{\mathrm{CH}_{3}-\underset{\mathrm{C}}{\mathrm{C}}-\mathrm{CH}_{8}}$ & 94.6 \\
\hline$\underset{\text { Ö }}{\mathrm{CH}_{3}-\mathrm{C}_{2}-\mathrm{C}_{2} \mathrm{H}_{5}}$ & adsorp. \\
\hline $\begin{array}{c}\mathrm{C}_{2} \mathrm{H}_{5}-\underset{\|}{\mathrm{C}}-\mathrm{C}_{2} \mathrm{H}_{5} \\
\text { O }\end{array}$ & 90.2 \\
\hline
\end{tabular}

Table 4. Elution volume of several solvents on PVA gel column using benzene as an eluent

\begin{tabular}{lrc}
\hline \multicolumn{1}{c}{ Sample } & $M . W$. & $\begin{array}{c}\text { Elution volume } \\
V_{\mathrm{e}} / V_{\mathrm{\iota}}(\%)\end{array}$ \\
\hline Ethyl acetate & 88 & 97.57 \\
Propyl acetate & 102 & 92.44 \\
Butyl acetate & 116 & 92.27 \\
Ethyl propionate & 116 & 90.73 \\
Ethyl methyl ketone & 72 & 101.34 \\
Diethyl ketone & 86 & 96.89 \\
\hline
\end{tabular}

酸エチルを溶媒としたときは，PEG-4000 の溶出がカラ ム容積に対してそれぞれ 103.0，111.7，138.2\% と羊れ て溶出する (Table 3 参照).

PEG が PVA ゲルに強く吸着する場合の溶出溶媒, 酢酸エチル，酢酸プロピル，酢酸ブチル及びェチルメチ ルケトンの PVA ゲルへの吸着の有無をベンゼンを溶出 溶媒として調べた.この結果を Table 4 に示した. 酢 
酸エチル，酢酸プロピル，酢酸ブチル，プロピオン酸エ チル, ジェチルケトン, エチルメチルケトンは分子量の 大きい順にほぼ正常位圆に溶出する．このことから溶出 溶媒自体は PVA ゲルに吸着しないことがわかる.

そこで PEG の PVA ゲルへの吸着の原因について検 討した．以上の実験に使用されたPVA ゲルは水で十分 に膨潤させた後メタノールで置換して使用されており， PVA ゲル中に水和水が残存していると考えられる. そ こでPVA ゲルを $50^{\circ} \mathrm{C}, 4$ 日間减圧乾燥し，これを(I) 脱水酥酸エチルで充てんしたカラム，(II) 水で十分膨潤 し,メタノール置換し，更に脱水酢酸エチルで直換して 充てんしたカラムを作製し，溶出溶媒として脱水酶酸エ チルを、試料として PEG-4000 の $5 \mathrm{wt} \%$ 䣫酸エチル 溶液を $30 \mu l$ 注入したところ, PEG-4000 はカラム (I) では溶出し, カラム (II) では吸着された.この結果, PEG の PVA ゲルへの吸着はゲルマトリックス中の水 和水の関与によることが明らかである.

溶出溶媒の種類によって PEG が吸着される場合と溶 出される場合がある点については溶解度パラメーター, 分配係数を調べて検討した. PEG またはェチレングリ コールが吸着する溶媒眽酸エチル，溶出が遅延する溶媒 プロピオン酸エチル，正常位置に溶出する溶媒ジィチル ケトンについてそれぞれ水との間の PEG またはェチレ

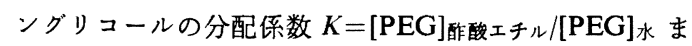
たは [EG]唒酸チル/[EG]水を測定したところいずれも0 $\sim 0.04$ の值を得た. PEG の 3 様の溶出挙動の原因につ いては,これら溶媒の間に分配係数にめいりょうな差が ないことままた溶解度パラメーターのにについても同様に 差がないことから明らかにできなかった。

\section{2 吸着量曲線}

酢酸エチルを溶出溶媒として用いて PEG を飽和吸着 させ, メタノールによって完全に脱着させる方法によっ て PVA ゲルカラムへの分子量の異なる PEG の吸着量 を測定した. 横軸に PVA $1 \mathrm{~g}$ 当たりに吸着した PEG のグラム数, 綎軸に PEG の分子量をプロットしたもの を Fig. 3 に示した. 分子量 10800 と 3550 の PEG の 吸着量はほぼ変らない．また分子量が小さくなるにした がって吸着量は增加した。 このことは分子量 10800 と 3550 の PEG は PVA ゲル中に浸透できずにゲル表面 のみで吸着され，分子量がれより小さくなるにつれて PVA ゲル内に浸透しやすいためにゲルマトリックス中 でも吸着が起こり吸着量が增加したものと考えられる。 この吸着量曲線は溶出溶媒としてメタノールを用いたと きの較正曲線と類似している. 以上の結果, PEG の吸 着は PVA ゲルマトリックス中の水和水の関与によっ て，PEG の分子サイズに応じてゲルマトリックス中で 行れると考えられる.

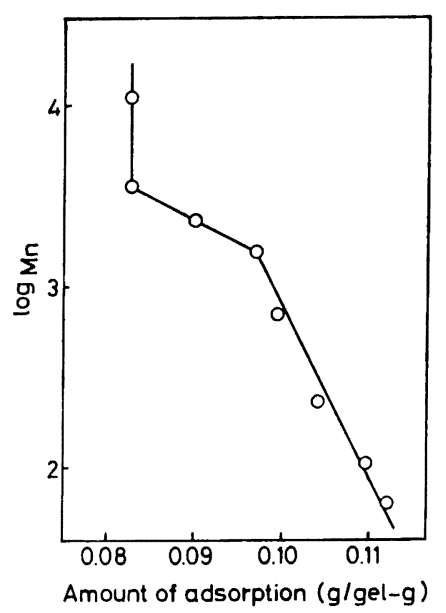

Fig. 3. Adsorption curve of PEG-4000 by PVA gel column. Eluant, ethyl acetate.

\section{4 結 論}

ポリビニルアルコールゲルカラムを用いて溶出溶媒と して各種溶媒を, 試料としてポリェチレングリコールを 溶出した結果, 次のことが結論される.

1) 溶出溶媒がメタノール，ベンゼンのときはポリェ チレングリコールは正常に溶出し，ギ酸エチル，酢酸メ チル，プロピオン酸オチルのときは遅延し，酢酸エチ ル, 酢酸プロピル, 酢酸プチル, エチルメチルケトンの ときは吸着される。

2）吸着された PEGはメタノールを溶媒とすること によって完全に脱着できる.

3) PEG の吸着は PVA ゲルマトリックス中の水和 水の関与によって PEG の分子サイズに応じてゲルマト リックス中で行れる.

\section{文献}

1) 本里義明, 平山忠一, 松本和秋, 工業化学雑誌, 74, 1904 (1971).

2) 本里義明, 平山忠一, 日本化学会誌, 1087 (1972).

3）平山忠一, 川口艁二, 本里義明, 日本化学会誌, 894 (1974).

4) 平山忠一, 本里義明, 日本化学会誌, 1352 (1975).

5) C. Hirayama, T. Honda, and Y. Motozato, Polymer, 18, 1227 (1977).

6) 中島章夫, 高分子化学, 7, 57 (1950).

7) JIS K 6726-1965.

8) K. A. Granath and P. Flodin, Makromolecules, 48, 160 (1961).

9) J. Brandrup and E. H. Immergut, "Polymer 
Handbook", 2nd ed, John Wiley \& Sons, New York (1975), p. IV-337.

Elution Behavior of Poly(ethylene glycol) through Poly(vinyl alcohol) Gel Column Using Several Solvents as Eluents

Chuichi Hirayama*1, Kazuaki Matsumoto*2, and Yoshiaki Motozato*1

${ }^{* 1}$ Department of Synthetic Chemistry, Faculty of Engineering, Kumamoto University (39-1, Kurokami 2 chome, Kumamoto, 860 Japan)

*2 Department of Industrial Chemistry, Ariake Technical College (150, Higashihagio, Omuta, 836 Japan)

$\gamma$-Irradiated poly(vinyl alcohol) beads, which were sufficiently allowed to swell in water, were washed with methanol, and then were packed into column. Gel chromatography was performed using methanol, benzene, esters and ketones as eluents and poly(ethylene glycol) as a sample. When the elution was carried out using methanol and benzene as eluents, elution behavior of samples was ordinary. When ethyl formate, methyl acetate and ethyl propionate were used as eluents, samples were slightly adsorbed and the elution was delayed. In the case the elution was carried out using ethyl acetate, propyl acetate, butyl acetate and ethyl methyl ketone as eluents, samples were adsorbed strongly on the bed material, and the adsorption curve was analogous to the calibration curve using methanol as an eluent. Dried poly(vinyl alcohol) gel as a packing material, showed ordinary elution behaviors for the samples. The adsorption of poly(ethylene glycol) on the present bed material was attributed to the existence of hydrated water on poly(vinyl alcohol) gel matrix.

KEY WORDS Adsorption / Poly(ethylene glycol) / $\gamma$-Irradiated Poly(vinyl alcohol) / Beads / Gel Chromatography / Methanol / Ethyl Acetate / Hydrated Water /

(Received December 9, 1982: Accepted August 10, 1983)

[Kobunshi Ronbunshu, 40 (12), 795-799 (1983)] 